\title{
Students Perception for English as a Second Language by using YouTube: A Case Study in Private University in Phnom Penh City, Cambodia
}

\author{
Nhor Sanhei*, Long Somnang**, Eing Kanyi **,Rozinah Jamaludin** \\ ${ }^{*}$ Center for Institution Technology \& Multimedia, Universiti Sains Malaysia \\ ${ }^{* *}$ College of Education, The University of Cambodia \\ ${ }^{* *}$ School of Management, Universiti Sains Malaysia \\ ${ }^{* *}$ Center for Institution Technology \& Multimedia, Universiti Sains Malaysia
}

DOI: 10.29322/IJSRP.10.08.2020.p104117

http://dx.doi.org/10.29322/IJSRP.10.08.2020.p104117

\begin{abstract}
The main purpose of this study was to figure out the student perception for English as a Second Language by using YouTube. The questionnaire of 19 items was sent to fifty ESL participation in a University in Phnom Penh City in order to identify students' interests of YouTube in ESL classroom and to find out the students' perceptions of using YouTube in ESL classroom. There were 50 participants who responded to the questionnaire and 22 males and 28 females. The result of the study illustrated that using YouTube is so significant and beneficial for the students in term of entertainment and educational purposes. YouTube is very common tool for all the users in order to deal with the various problems. Moreover, YouTube is the most popular website as well. More researches ought to be directed progressively about the four strengths by using YouTube to join any instructing and learning approaches in the 21 st century. Besides, this research ought to be led in the exploratory research.
\end{abstract}

Index Terms- Students perception, English as a Second Language, YouTube, ESL

\section{INTRODUCTION}

C ambodia is one of the ASEAN nations, with the remaining ten nations to become a member of it in 1999 (Frost, 2008). In 2019 the population of Cambodia had grown to over 16 million people (World Bank, 2020). Cambodia has 25 provinces, including the city of Phnom Penh (UNDP, 2019).

The English language has been an important tool for Cambodian students who set themselves up to grasp the worldwide economy (Sothy et al.,2015). As Clayton (2002) puts it, English is a most widely used language all through the nation since the nearness of the United Nations Transitional Authority in Cambodia (UNTAC) in 1993. From that point forward, English has been one of employment necessities in different work over the country.

Technology plays the important role for the modernization and civilization society. Especially, for the generation, who is living in the industry 4.0 acquired the technology and skill base (Anbumozhi \& Kimura, 2018). YouTube is the world's largest client-driven video service provider; it has become a noteworthy stage for the dispersal of mixed media data (Wattenhofer et al., 2012).

English is the popular language and is used for business and international education (Crystal, 2012). There are two political activities in Cambodia promote the use of the English language: the UN Transitional Authority period in Cambodia (UNTAC) during 1992-1993 and the entry of Cambodia to the Association of Southeast Asian Nations (ASEAN) in 1999 (Igawa, 2008).

Cambodia recently, English language is a demand because it is so important for better career and as well as in a good living condition (Hashim et al., 2014). Most of Cambodian students try to study English, but somehow, English is still the challenges or barrier for them to pursue higher education (Chea, 2015). Igawa (2008) stated that English language education is a boom in Cambodia and Communicative competence in English means a better job and a better pay.

For the function of YouTube, it was found that the use of YouTube videos to learn English is still a recent concept, which can be used effectively to promote language learning in the classroom (Zaidi et al., 2018). Roodt and De Villiers (2011) further claimed that using YouTube as a platform to facilitate collaborative learning. In addition, using YouTube in the classroom can also present a challenge, as it can be both difficult and time-consuming to locate relevant and class-related material in YouTube's huge video storage, 
particularly if the lecturer does not have a specific video clip (Burke, Snyder \& Rager, 2009). As the above mentioned, this study is to investigate the student's perception of English as a Second Language by using YouTube.

Research Objectives: There were two precise objectives for this research study; to identify students' interests of YouTube in ESL classroom; to find out the students' perceptions of using YouTube in ESL classroom.

\section{LITERATURE REVIEW}

Perception is the capacity of a person to be conscious of what is going on in their world and to understand it. Theories of perception have developed around how the mind processes, knowledge that the sensory organs- eyes, ears, nose, and skin-send to it. These organs transmit signals to the brain, use them to create memories, make decisions and comment on issues. Hallucinations, veridical hallucinations and visual illusions are the different forms of experiences used in the theories of perception. (Hoffman, 2015).

YouTube is also an online website for video sharing that allows you to transfer content to your personal YouTube Channel made by you or others. YouTube features comment threads you can monitor on your channel and videos, as well as a tracker that lets you track who is watching your videos (YouTube, 2011). Cheng et al., (2008) reported that since its launch in early 2005, YouTube has been the most popular Internet platform offering a new generation of short video sharing services. However, the use of a range of teaching methods and learning activities in the classroom or through online training will help enhance students ' learning environment (Fill \& Ottewill, 2006).

Research on using YouTube in the classroom is typically a recent area of research. By contrast, the use of YouTube and other ICT resources in language learning has become worldwide a well-known dialogue. A few researchers from various nations recommended that utilizing ICT in the classroom is ending up increasingly predominant in coming years (Klimova \& Poulova, 2014; Teo et al., 2008). In the digital Education, the trade of using ICT, significantly YouTube encourages students to learn more actively and interactively. In addition, Mishna et al., (2009) claimed that, as a means of communication and socialization, the use of technology like the Internet is more than any other process

\section{III.METHODOLOGY}

Purposive sample will be applied in English as a Second Language class and it will be adopted to select the participants for this research. Purposive sampling, one of the most common sampling techniques, group participants on the basis of pre-selected parameters related to a particular research question (Mack, 2005). For this reason, purposive sampling is most effective when data review and analysis are carried out in conjunction with data collection (Mack, 2005).

In addition, the researcher utilized this testing strategy to pick just the normal and savvy scholarly execution understudies to take an interest in this study.

Instruments are adopted from Balbay and Kilis (2017).

\section{Questionnaire Design}

Appendix A shows the sample questionnaires about Students Perception for English as a Second Language by using YouTube

Table 1 Distribution of items

\begin{tabular}{|l|l|l|l|}
\hline Appendix & Type & References & No. of Items \\
\hline A & Section (A) Respondents details & \\
\cline { 2 - 4 } & Section (B) Respondents' questionnaire in using YouTube \\
\hline Perception & $\begin{array}{l}\text { Student Perception for } \\
\text { English as a Second } \\
\text { Language by using } \\
\text { YouTube }\end{array}$ & $\begin{array}{l}\text { Adopted from Balbay } \\
\text { and Kilis (2017). }\end{array}$ & 9 items \\
\hline
\end{tabular}

This publication is licensed under Creative Commons Attribution CC BY. 


\section{Data Analysis}

In this study, Quantitative data is examined by using Statistical Package for the Social Sciences (SPSS) in descriptive data.

\section{RESULTS AND DISCUSSION}

For the purpose of this research, data are described in numbers, percentages and mean.

\subsection{Demographic Profile of Students}

A total of 50 students responded to the questionnaire which has two different sections. See the following tables respectively:

Table 1 Gender, Age, Year \&Marital Status

\begin{tabular}{llll}
\hline Respondents & Description & No. of respondents & Percentage (\%) \\
\hline \multirow{3}{*}{ Gender } & Male & 22 & 44 \\
& Female & 28 & 56 \\
& Total & 50 & 100 \\
\hline \multirow{4}{*}{ Age } & Under 20 & 7 & 14 \\
& $20-25$ & 37 & 76 \\
& $26-30$ & 4 & 8 \\
\hline \multirow{4}{*}{ Year } & More than 30 & 1 & 2 \\
& Total & 50 & 100 \\
\hline \multirow{3}{*}{ Marital Status } & Second & 37 & 74 \\
& Third & 9 & 18 \\
& Fourth & 4 & 8 \\
& Total & 50 & 100 \\
\hline
\end{tabular}

Table 1 showed that the participants of 50 responded to the questionnaire which $44 \%$ male and $66 \%$ female. Moreover, the highest age group (20-25) is $76 \%$ of the participants and most of the respondents are from the Second year. Additionally, $98 \%$ of respondents are still single.

Table 2 Experiences of students using YouTube

\begin{tabular}{|c|c|c|c|}
\hline Respondents & Description & $\begin{array}{l}\text { No. of } \\
\text { respondents }\end{array}$ & $\begin{array}{l}\text { No. of } \\
\text { respondents }\end{array}$ \\
\hline Experience of using YouTube & $\begin{array}{l}\text { Everyday } \\
\text { Only at Weekend } \\
\text { Rarely } \\
\text { Total }\end{array}$ & $\begin{array}{l}38 \\
9 \\
3 \\
50\end{array}$ & $\begin{array}{l}38 \\
9 \\
3 \\
50\end{array}$ \\
\hline $\begin{array}{l}\text { How often do you use You } \\
\text { Tube }\end{array}$ & $\begin{array}{l}\text { For Entertainment } \\
\text { To Improve my English } \\
\text { Total }\end{array}$ & $\begin{array}{l}28 \\
22 \\
50\end{array}$ & $\begin{array}{l}28 \\
22 \\
50\end{array}$ \\
\hline Have you ever use You Tube & $\begin{array}{l}\text { Yes } \\
\text { No } \\
\text { Total }\end{array}$ & $\begin{array}{l}48 \\
2 \\
50\end{array}$ & $\begin{array}{l}48 \\
2 \\
50\end{array}$ \\
\hline Why You Tube is beneficial & $\begin{array}{l}\text { I didn't know which playlist to watch. } \\
\text { I wasted my time finding examples. }\end{array}$ & $\begin{array}{l}17 \\
20\end{array}$ & $\begin{array}{l}17 \\
20 \\
13\end{array}$ \\
\hline
\end{tabular}



I figured that all those examples were
good examples.

Total
50
50

Table 2 showed that $67 \%$ of the respondent had the experience of using YouTube almost every day. In contrast, 56\% of respondents use YouTube for the entertainment. However, $44 \%$ of this participant watches YouTube in order to improve their English. Additionally, either watching YouTube for entertainment or academic purposes, it would be awesome for their living. Surprisingly, 40\% of respondent consider watching YouTube as wasting their time.

Table 3 The Student's Perception of using YouTube

\begin{tabular}{lll}
\hline Description & Mean & Std. Deviation \\
\hline $\begin{array}{l}\text { Discussing the videos on YouTube makes the class } \\
\text { more interesting. }\end{array}$ & 4.20 & 0.75 \\
\hline $\begin{array}{l}\text { It has been more effective to use YouTube in class } \\
\text { than to look at slides. }\end{array}$ & 3.12 & 0.95 \\
\hline $\begin{array}{l}\text { The YouTube videos in classroom motivated me to } \\
\text { improve presentation }\end{array}$ & 3.44 & 0.91 \\
\hline $\begin{array}{l}\text { The YouTube videos in classroom motivated me to } \\
\text { watch more presentations than those on the playlists }\end{array}$ & 3.24 & 0.91 \\
\hline $\begin{array}{l}\text { The YouTube videos used in class enhanced my } \\
\text { participation in the classroom. }\end{array}$ & 3.22 & 0.84 \\
\hline $\begin{array}{l}\text { Usage of YouTube videos improved my } \\
\text { comprehension of the substance of the lesson }\end{array}$ & 3.32 & 0.96 \\
\hline $\begin{array}{l}\text { Watching classroom YouTube videos had positive } \\
\text { results on improving my presentation skills }\end{array}$ & 3.62 & 0.79 \\
\hline $\begin{array}{l}\text { YouTube videos provide a clear source for listening } \\
\text { comprehension practice. }\end{array}$ & 3.98 & 0.86 \\
\hline $\begin{array}{l}\text { If I were an instructor, I 'd use videos from YouTube } \\
\text { in my classes. }\end{array}$ & 3.56 &
\end{tabular}

According to the results above, the descriptive statistics showed that the student's perception of YouTube videos being more interesting had a mean score of 4.20 over 5.00 and a standard deviation of 0.75 . The results showed that using YouTube in class was more effective than watching slides $(\mathrm{M}=3.12, \mathrm{SD}=0.98)$, the YouTube videos in classroom motivated me to improve presentation $(\mathrm{M}=3.44, \mathrm{SD}=0.95)$, the YouTube videos in classroom motivated me to watch more presentations than those on the playlists $(\mathrm{M}=3.24$, $\mathrm{SD}=0.91)$, the YouTube videos enhanced my participation in the classroom $(\mathrm{M}=3.22, \mathrm{SD}=0.91)$, usage of YouTube videos improved my comprehension of the substance of the lesson $(\mathrm{M}=3.32, \mathrm{SD}=0.84)$, watching classroom YouTube videos had positive results on improving my presentation skills $(\mathrm{M}=3.62, \mathrm{SD}=0.96)$, YouTube videos provide a clear source for listening comprehension practice $(\mathrm{M}=3.98, \mathrm{SD}=0.79)$, and If I were an instructor, I 'd use videos from YouTube in my classes $(\mathrm{M}=3.56, \mathrm{SD}=0.86)$.

\section{CONCLUSION}

This descriptive study has illustrated the student perception of English as Second Language by using YouTube that divided into different sections: student perception of using YouTube that most of the participant experience of using it and it is used in the entertainment and in the educational purposes. The overall perceptions were pretty well. It can be clear clarified on the perceptions on using YouTube: the YouTube videos in classroom motivated me to improve presentation (M=3.44, SD=0.95), the YouTube videos enhanced my participation in the classroom $(\mathrm{M}=3.22, \mathrm{SD}=0.91)$, watching classroom YouTube videos had positive results on improving my presentation skills $(\mathrm{M}=3.62, \mathrm{SD}=0.96)$, YouTube videos provide a clear source for listening comprehension practice $(\mathrm{M}=3.98$, $\mathrm{SD}=0.79)$, If I were an instructor, I 'd use videos from YouTube in my classes $(\mathrm{M}=3.56, \mathrm{SD}=0.86)$.

This study is applicable on the effects of student perception for English as a Second Language by using YouTube among Cambodian university students. It may pave the way for the universities to implement and integrate Information Communication and Technology (ICT) tools into their existing curriculum. YouTube is very common tool for all the users in order to deal with the various problems. Moreover, YouTube is the most popular website as well.

This publication is licensed under Creative Commons Attribution CC BY. 
More researches ought to be directed progressively about the four strengths by using YouTube to join any instructing and learning approaches in the 21st century. Such investigations will noteworthy to researchers, teachers, and students in the further proficient improvement and future profession advancement in instruction area. Besides, it ought to be led in the exploratory research.

Based on the finding of this study; teachers, universities, and the Ministry of Education, should provide training to equip the Cambodian students to be ready regarding the knowledge-based web 2.0 tools, especially YouTube, which will become increasingly significant for both students and teachers in term of teaching and learning process.

\section{REFERENCES}

[1] Anbumozhi, V., \& Kimura, F. (2018). Industry 4.0: Empowering ASEAN for the Circular Economy.

[2] Balbay, S., \& Kilis, S. (2017). Students' Perceptions of the use of a YouTube channel specifically designed for an Academic Speaking Skills Course. Eurasian Journal of Applied Linguistics, 3(2), 235-251

[3] Burke, S. C., Snyder, S., \& Rager, R. C. (2009). An assessment of faculty usage of YouTube as a teaching resource. Internet Journal of Allied Health Sciences and Practice, 7(1), 8.

[4] Chea, N. (2015). HIGHER EDUCATION IN CAMBODIA Poor rural female students' challenges, motivations, and coping strategies.

[5] Cheng, X., Dale, C., \& Liu, J. (2008, June). Statistics and social network of youtube videos. In 2008 16th Interntional Workshop on Quality of Service (pp. 229-238). IEEE.

[6] Clayton, C. E. (2002). Life without transcriptional control? From fly to man and back again. The EMBO journal, 21(8), $1881-1888$.

[7] Crystal, D. (2012). English as a global language. Cambridge university press.

[8] Fill, K., \& Ottewill, R. (2006). Sink or Swim: Maximising the potential of video streaming. Innovations in Education and Teaching International, 43(4), 397-408.

[9] Frost, F. (2008). ASEAN's Regional Cooperation and Multilateral Relations: Recent Developments and Australia's Interests. Parliamentary Library.

[10] Hashim, A., Chee Leong, Y., \& Tra Pich, P. (2014). English in higher education in Cambodia. World englishes, 33(4), 498-511.

[11] Hoffman, D. D., Singh, M., \& Prakash, C. (2015). The interface theory of perception. Psychonomic bulletin \& review, 22(6), 1480-1506

[12] Igawa, K. (2008). English language and its education in Cambodia, a country in transition. Shitennoji University Bulletin, 46(1), 343-369.

[13] Klimova, B. F., \& Poulova, P. (2014, February). ICT as a motivational tool in the learning of foreign languages. In Proceedings of the 2014 International Conference on Educational Technologies and Education (pp. 53-56).

[14] Mack, N. (2005). Qualitative research methods: A data collector's field guide.

[15] Mishna, F., Saini, M., \& Solomon, S. (2009). Ongoing and online: Children and youth's perceptions of cyber bullying. Children and Youth Services Review, 31(12), 1222-1228.

[16] Roodt, S., \& De Villiers, C. (2011). Using YouTube as an innovative tool for collaborative learning at undergraduate level in tertiary education. In Proceedings of the AIS SIG-ED IAIM 2011 Conference (pp. 1-13).

[17] Sothy, K., Madhur, S., \& Chhem, R. (Eds.). (2015). Cambodia Education 2015: employment and empowerment. Cambodia Development Resource Institute.

[18] Teo, T., Chai, C. S., Hung, D., \& Lee, C. B. (2008). Beliefs about teaching and uses of technology among pre-service teachers. Asia-Pacific Journal of Teacher Education, 36(2), 163-174.

[19] UNDP (2019). HUMAN DEVELOPMENT REPORT CAMBODIA 2019. Retrieved from https://www.google.com/url? sa=t\&rct=j\&q=\&esrc=s\&source=web\&cd=\&cad=rja\&uact=8\&ved=2ahUKEwir8OHwuOXqAhUZ7nMBH Sa7DAsQFjAAegQIBRAB\&url=http\%3A\%2F\%2Fhdr.undp.org\%2Fsites\%2Fdefault\%2Ffiles\%2Fnhdr_cambodia.pdf\&usg=AOvVaw3 L7rWhtyTTsG4HH-xd-w2C

[20] Wattenhofer, M., Wattenhofer, R., \& Zhu, Z. (2012, May). The YouTube social network. In Sixth International AAAI Conference on Weblogs and Social Media.

[21] World Bank (2020). Data Indicator. Retrieved from https://data.worldbank.org/indicator/SP.POP.TOTL?locations=KH\&view=chart

[22] YouTube, L. L. C. (2011). YouTube. Retrieved, 27, 2011.

[23] Zaidi, A., Awaludin, F. A., Karim, R. A., Ghani, N. F., Rani, M. S. A., \& Ibrahim, N. (2018). University students' perceptions of YouTube usage in (ESL) classrooms. International journal of academic research in business and social sciences, 8(1), 541-553.

\section{AUTHORS}

First Author - Center for Institution Technology \& Multimedia, Universiti Sains Malaysia, Email: sanheinhor@gmail.com

Second Author - College of Education, The University of Cambodia, Email: education@uc.edu.kh

Third Author - School of Management, Universiti Sains Malaysia, Email: eingkanyi@gmail.com

Fourth Author-Center for Institution Technology \& Multimedia, Universiti Sains Malaysia, Email:

rozinah@usm.my 
International Journal of Scientific and Research Publications, Volume 10, Issue 8, August 2020

Correspondence Author - Center for Institution Technology \& Multimedia, Universiti Sains Malaysia, Email: sanheinhor@gmail.com 